\title{
Analysis of Jurisprudence - Legal of Compulsion and Duress in
}

\section{Adultery}

\author{
Mahmoud Haeri ${ }^{1}$ \\ ${ }^{1}$ Faculty Member, Yazd University, Yazd, Iran \\ Correspondence: Mahmoud Haeri, Faculty Member, Yazd University, Yazd, Iran. E-mail: mhaery@yazd.ac.ir
}

Received: January 21, 2016 Accepted: February 16, 2016 Online Published: March 31, 2016

doi:10.5539/jpl.v9n2p89 URL: http://dx.doi.org/10.5539/jpl.v9n2p89

\begin{abstract}
Criminal responsibility is communicative ring and bridge of two important institutions of criminal law, crime and punishment and therefore is one of the most important issues of criminal law.

On the other hand, one of the conditions of obligation and criminal responsibilities is authority and freedom of action that a person could be required to preserve and respect for life, property and dignity of the people that in the actions is autonomous and free.

Although our legislator is considered to this issue in discretionary (Tazir) punishments crimes and life retribution explicitly and in the Haddi crimes are pointed to the lack of coercive responsibility, however, coercive criminal responsibility isn't specified in all instances of mentioned crimes, while in the discretionary (Tazir) punishments crimes, coercion is spiritual steward and is responsible for criminal responsibility due to the force committed crime and in the crime led to the death, in some cases crime is attributable to the duress, in the crimes included Hadd, coercing isn't considered spiritual steward.

In this paper, the mentioned issue is discussed in terms of legal and regulatory concerning the crime of adultery.
\end{abstract}

Keywords: coercion, duress, adultery, criminal responsibility

\section{Introduction}

Criminal responsibility discusses of the attributes and conditions that provide the reasonable possibility of imposing penalties on offense.

Criminal responsibility is the duty of the person in response to a result of criminal act, ie someone before commit a criminal act against the violation of commandments of legislator, has legal responsibility that after the crimes will have obligation to accept of penalty or criminal liability, this means that every human takes responsibility of undesirable and consequences that he himself is committed from understanding and control and deliberate, because he has had the required competency, known good and evil completely and has been informed from the results and effects of his good and bad work.

Since the offenses in the Penal Code, due to legal sources is mentioned as criminal of Haddi punishments are in part of intentional crimes, so unintentional isn't realized but bearing much heavier penalties for those who willingly and without coercion are committed crimes.

According to Article 139 of the Penal Code, adopted on 2011 criminal responsibility is realized when person during the commission of the offense is rational, mature and free.

In this article, committed the crime of adultery by people who are affected by duress and compulsion and criminal responsibility of persons who forced them to commit mentioned crime based on legal sources and former IPC and recently approval, will be investigated in detail.

The first speech: the concept of duress and compulsion

A) The concept of duress:

Authority in word is defined as freedom and power to do the work on his volition. (Moein, 1992, 169)

Autonomous is also the one who chooses what is asked, therefore, if the offense isn't the results of subject and his volition isn't established on committing mentioned act, the crime cannot be put to his account and reprimanded from him. 
In a definition is said: duress, forcing another to create what is reluctant to provide it with frightening to leave it that actually makes something for him in terms of loss of his life. (Esfahani, Seyed Abolhasan, 2006, 281)

In another definition is: the truth of reluctance in terms of word forcing someone else to do the act or leave an act that is reluctance and disdain. (Ragheb Esfahani, 1990, 429)

Therefore, in the definition of duress can be said: applying illegal material or spiritual pressure on others so that force him in spite of desire for fear of damage to the body and soul or significant harm to perform work or leave the task.

B) the concept of compulsion:

Compulsion is force and source means force, inevitable, dominance, non -authority, commitment and challenge. (Moein, 1215)

Compulsion means forcing to perform the work, without that the person has the slightest intention and authority.

Compulsion is a situation that causes deterioration of free will of the obliged person, at the time the committed crime so forcibly deprive the decision and the loss of intention and will.

What is certain, there is a difference between compulsion and duress and cannot consider them the ablative cause of criminal responsibility, because in the duress person, satisfaction isn't existed simply and its cause is unusual illicit material and spiritual pressure, which is caused, this pillar is overthrown.

But duress person despite the lack of internal satisfaction, intent to criminal act or omission, that is a crime, whereas in force in addition to overthrowing satisfaction in obliged person, not exist intent to commit offense or intent to omission that is a crime, because threat and intimidation and physical and spiritual means of coercing person, submitted him to the violent action, it seems that compulsion is more intense than duress.

However, the legislator after the revolution, in Article 29 of the Islamic Penal Law and in Article 54 of the Penal used two words of compulsion and duress synonymously.

However, in Article 41 of the penal code in 1925 and Article 39 of the amended Act in 1973 just was satisfied to mention the word of compulsion, and in article of 150 of the Penal Code, adopted in 2011 has pointed to the crimes committed in the duress mode, and expressed that "if anyone due to intolerable duress committed a crime which considered crime according to law, not punish, in crimes of Tazir, duress person is sentenced to punish the perpetrator of the offense, in criminals cause Hadd and death is treated according to the relevant regulations" .

Mention Tazir punishments or deterrent in Article 54 of the Penal Code of the former as well as Tazir punishments in law of Islamic Punishment Act of 2011, should not be under the illusion that otherwise would be not used the force as the ablative cause of responsibility in such cases, should act in other cases stated in law, according to Article 167 of the Constitution and article 214 of the Criminal Procedure Code refer to the respective chapters in law or in accordance with the general principles, in this context, jurisprudential - legal judgments is discussed in two separate speech of compulsion and duress in adultery.

Second speech: compulsion and duress provisions than coercion.

Penal Code (1991), having authority in crimes involving the adultery, sodomy, lesbianism, intoxication, theft, Articles 64, 111, 113, 166 and 198 considered the condition of proof of punishment, in the reform law of recent approval generally in Article 218 states that "in crimes of Hadd when accused person claims the lack of knowledge or intent of barriers of criminal responsibility at the time of the committed crime, if there is the probability of truth of his speech... mentioned claim is accepted without the need for evidence and swear" According to previous topic content, compulsion and duress provisions are investigated in the crime of adultery in terms of coercion.

Discussion of compulsion and duress in adultery that is disputed by the jurists in legal books is the possibility or impossibility of its realization for the adulterer or adulteresses which will be investigated separately.

A: duress of adulteresses

Quality of adultery is in a way that usually when the woman claims reluctant if there is specified conditions in duress, his claim is accepted and jurists are unanimous on this issue, narratives of the infallible Imams (AS) were also suggest that confirm it.

Imam Sadegh (AS) about the woman who confessed to adultery, but claims duress said the woman is free that not have a will of its own, then if the man wanted, would kill her, the woman is not flogging and stoning. (Ameli, Vasayelolshie, 1401, 382) 
If the adulterer forced adulteresses to commit adultery, assuming fulfillment of the conditions of compulsion or duress, there no difference in the penalty of adulterer that death is as his Hadd and lack of criminal responsibility of adulteresses, consensus among scholars is that duress about the woman is realized and to avoid obligation and according to the prophetic tradition, with the realization of duress, the effect of sanctions to coercion is overthrown and in the Islamic penal reform in paragraph of Article 225 expressly mentioned "adultery Hadd is death for following cases ... D: adultery to rape or duress by the adulterer that caused death of adulterer"

(B) duress of adulterer

For men, it is said that "duress prevents physical fitness and arousal of sexual force, because the two are incompatible on the desire of the soul and the soul's desire with the withdrawal of the soul from the work, but obviously, it is possible because physical fitness occur of appetite and this is something natural and religious reverence not contradict with it, however, and there is no Hadd to man, because there is doubt and Hadd is repulsed with doubt."(Mohammadi, 1995, 9)

According to the theory of jurists, the realization of compulsion and duress in adultery, about woman and about mean is possible, so the legislator in former law of Islamic punishment had accepted Article 67 of duress about adulterous and absolute phrase of "accused" in Article 218 of the recent approval of Penal Code is guaranteed this issue and in its functions was possible sodomy, lesbianism, Tafkhiz and leadership in the case of existing all condition of compulsion or duress, and consequently due to lack of elements of criminal responsibility, the authority and discretion of the subject not imposed punishment on coercion.

In Article 67 of the former Penal Code and Article 218 of Reform Act 2011 legislator, has accepted deviating from the former view of realization by the adulterer.

Third speech: compulsion and duress provisions in adultery than coercion

According to Article 150 of the Penal Code, adopted in 2011, "If someone committed a behavior due to unbearable duress that is considered a crime under the law, not punished, in crimes of ta'zir, duress person is sentenced to the punish the perpetrator of the offense, in crimes cause Hadd and death is treated according to the relevant regulations".

Law regarding the criminal responsibility of someone that force other to committing one of the crimes included Haddi punishments is silent and if acting coercion is considered with the realization of required conditions of the commission in committing some crimes, such as robbery and crimes that their law punishments is Haddi whip, lead to punishments provided in sections B and C of Article 216 of the law, that in this article will be explained more about this issue in other cases should implement in Article 167 of Constitution and Article 214 of the Code of Criminal Procedure, citing valid and reliable legal sources in accordance with the general principles.

In this section, citing sources and principles, criminal responsibility of coercion in the crime of adultery is studied.

About adultery should separate a sentence of man that forced a woman to commit adultery with him with a case that a woman forced a man to commit adultery with her and third case that force them to commit adultery with each other.

A: duress of adulteresses by adulterer

In the first assumption, if a man forced a woman in adultery, and exceed her by force, two liability is imposed on duress person, the criminal responsibility, the penalty for adultery, that based on verdicts in terms of Article 225 paragraph D Penal reform law, the death is the penalty of adulterer that as Hadd punishment is determined for him.

In addition to duress criminal responsibility in this case, he, according to jurists, is obliged to pay dowry of woman "because dowry is instead of genitals, when it is unlawful and without dowry is as the price of wasted property, although the lack of use it would not guarantee, even if it would guarantee and because such a woman isn't adulterer and prevention of woman dowry signifies the proving dowry for non him."(Mohammadi, 9)

Law of reforming Islamic punishment following the theory of jurists in Article 229 states that "in cases of rape and in its sentences, if the woman is virgin, committed in addition to the punishment is condemned to the payment of virgin and dowry, otherwise is condemned to pay dowry and punishment" .

As well as under Article 652 of the law "when defloration is made other than partner by finger or with other thing and without consent, caused paying dowry.

Note 2: The consent of an immature or insane girl that has no real satisfaction to adultery is in rule of 


\section{dissatisfaction" .}

But the question that arises here is that when a man steals a woman and forced her to commit adultery, what is the punishment of adulterer?

Since the verdict of this issue in the Islamic punishment law in 1991 and 1996 was not clear, for it was given different answers .

One answer was that this is an example of a multiplicity of spiritual offense, the perpetrator carried out the operation that two criminal titles apply on it, therefore, in accordance with Article 46 of the Penal Code 1991, punish of criminal is applied, which its punish is severe, something that was wrong, was about crimes of Tazir, however one of the cases was Haddi and other was discretionary.

Other responses was that Article 82 dissuading adultery with the kidnappers, because this crime is with the specific law that the same Article 621 is the law of sanctions adopted in 1991 for this response there was an approval, that the phrase of "any other purpose and "prestige injury "under the article, including the kidnapping could lead to adultery, the answer according to the characteristics of the legal system of Islam, that put Hudud in the privileged position to sanctions, is not acceptable, because cannot ignore Hadd and sufficient to punishment.

The third response was that Article 621 refers to the state that kidnapping not lead to adultery, but when the kidnapping leads to adultery, two possibilities were discussed, a possibility was that just Hadd punishment is done, the other was that in addition to the Hadd punishment, kidnapping punishment was sentenced, the first possibility was more compatible with legal rules, because if the crime of kidnapping was led to adultery, was only the introduction of the adultery that so-called barrier crime, therefore, when a major crime is realized that is adultery, the separate punishment could not be considered to barrier crime.

Second possibility was more consistent with the Article 621 because the following article stipulates that "in case of committing other crimes, sentenced to the punishment for the offense." This case was included because two crimes had occurred here; in addition, the rules of plurality of crime, dedicated to crime of discretionary and where discretionary crime with Haddi crime occurred, any crime had its own punishment.

But now, according to the clear wording of Note 2, Article 225 of the Penal Code Act 2011 which provides that "if anyone commit adultery with a woman that she is not satisfied to adultery with him, in unconsciousness, sleepiness or drunkenness, his behavior is in sentence of rape, and also it is the same in adultery through deception and deceiving the immature girl or through kidnapping, threatening or intimidating woman, but caused yield him. "Punish of committing such a practice as called crime according to the provisions of Clause 2, Article 133 of the law that stipulates that "if the total crimes committed in law has certain criminal title, the provisions of plurality of crimes, does not apply and commit to the penalty prescribed in the law will be condemned." Thus, the death penalty under Article 225 of the law is condemned.

(B) Duress of adulterer by adulteresses

Clear provisions of article 64 and 67 of the former Penal Code and Article 218 of Reform Act, suggests that the legislator has accepted realizing duress from man, so it may be a woman forced a man to commit adultery with her .

Here's the question that comes to mind is whether the punishment of duress woman is death or other penalties applied about her?

Of the paragraph "D" Article 225 that stipulates "punishment Hadd for adultery in the following cases is death ... D: rape adultery or duress from adulterer, which caused adulterer to death." It is concluded that the death penalty is not done about his, because the word "adulterer" in this article, is about the adulterer and not included the adulteress, but this detail is not so logic, either an approval that there is for no difference is that legislator has had view to prevailing case, for men caused duress of woman and the woman does not have such power, because in terms of physical strength, man is stronger that woman, man is essentially in the state of compulsion and duress not have sexual desire to be able to operate closeness with the specific meaning of adultery.

In any case, strict interpretation of the law and stick to the text, requires that death penalty only is in the case of obliged man, of course, this statement does not mean that the realization of the duress from the women isn't possible to man, so a woman who forced a man to committing adultery with compulsion and duress as appropriate, will be subject to one of the other punishments for adultery.

A: duress from the third party

This assumption is when the third party forced man and woman into adultery with one another, what for in Article 67 of the former Penal Code and Article 218 law of recent approval has been pointed out is duress of 
adulterer or adulteress and in particular whether the duress of couple is possible, if yes, how is punish of the third party that has forced them to commit adultery, not pointed to them in mentioned cases.

Article 67 of the former Penal Code was concluded that the duress of men and women together was not possible because the legislator in the mentioned Article was used the word "or", but this interpretation was not so correct, because the legislator view refers to the standard case and prevailing that duress in one party is realized, but there is no rationale for the exclusion of sentence of realization of duress of adulterer and adulteresses together, now reform act is used the word of accused absolute in Article 218 and finished the disputes.

But about the third party that forced adulterer and adulteresses to commit adultery, two questions are raised first, how is criminal responsibility of duress and second who is responsible for the payment of dowry of the woman, adulterer or duress?

In response to the first question, jurists and lawyers believe in coercion or duress is done crime, but because cannot be attributed to the offender, so coercing is lack of criminal responsibility and will not be punished, of course, about discretionary crimes, believe that the obligation is sentenced to the crime punish that in Article 54 of the former Penal Code and Article 150 reform Act has adopted the same idea, in fact, because it can be said that the duress collects the elements of forming crime in itself and has used the coercion as a means to commit a crime, as in Article 225 of the Islamic Penal Reform Act has been described, the death penalty just is about duress from adulterer, so the use of Article 150 of the recent approval of Penal Code about the third party, primarily due to the clear wording of that it's just considered necessary in Tazir crimes and, second, in accordance to paragraph (D) Article 225 of the law, seems impossible and illegal, in response to this question can express four views.

.1Carry third duress practice to prostitution, arguing that prostitution, as defined by scholars is the "comprehensive relationship between men and women for adultery" (F. Hendi, 1409, 507) and here duress person has gathered man and woman for adultery, but this argument is not correct, because in prostitution, only man and woman are with each other and they willingly and voluntarily commit adultery with each other and, in fact, man and woman who are willing to commit adultery collect together, and provide introducing them and man and woman willingly have sexual intercourse with each other.

.2The second solution is the use of Article 638 of the Penal Code "sanctions" that it is allowed to be present and obvious and otherwise the use the Article 638 to determine the third party punishment is not correct.

.3Using title of threat and duress of Article 669 of the Penal Code Act 1991, pursuant to the provisions of "everyone threats another in any way to kill or harm of soul or and dignity or property, or to disclose the secret to themselves or relatives, whether is asked for fund demand or demand of omission or not, flogging up to 74 lashes or imprisonment up to two month to two years will be condemned".

As is obvious, the legislator in Article 669 is determined the absolute of threat as the criterion and its realization is not bound by the outcome, so threat to kill or harm of soul, dignity, property, or disclosure the secret, to achieve the objective of this matter is sufficient and there is no need that committed by applied threat, intent to property demand or doing a crime from duress.

According to Article 202 of the Civil Code 'duress is acts that is affected in person or wisdom and threat him in relation to life or property or his reputation in a way that normally cannot be tolerated".....

Accordance with the provisions of this Article, the duress is that the man is threatened to his life, property and reputation, and in duress to Haddi crimes with realization of duress condition, duress person is threatened to life or property or his reputation, it can be said that if someone forced another one to commit one of the Haddi crimes such as adultery, sodomy and the self not be steward ...... is included to Article 669 of the Penal Code.

.4Using the title of deputy in the Haddi crime and determining discretionary punishment on the perpetrators, about some of the offenses, the legislator explicitly to the deputy, the independent penalty is considered or in some cases deputy independently from the legislature is considered crime in this case, the use of Article 126 of the Islamic Penal law Act of 2011 which states that "if in the law no determine other punishment for deputy, the punishment include the following ... (b) in Haddi robbery and intentional cut of a member, imprisonment suspended five or six degree $\mathrm{C}$ : in the crimes that their legal punishment is whipping, thirty-one to seventy four lashes grade six".

Article 68 of the law also states that "perpetrators of crimes that the type or amount of punishment is not determined in enacted laws, sentenced to alternative punishment." Duress punishments in Haddi crimes is Tazir penalty, it seems that in some cases that the type or amount of the penalty was unknown to them in law, be able to sentence them base on the provisions of this Article to one of the punishments of alternative of imprisonment, 
under Article 63 of the law.

The article provides for "alternative sentences of imprisonment is the episode of care, free public services, fines, daily fines and deprivation of social rights"...

This issue was one of the shortcomings of all Islamic penal code after the revolution, including the recent approval law that legislators need to act to fix it, to be prevented from issued of opinions and conflict rulings, it should be noted that according to Article 19 of the law, Tazir penalties for persons divided to eight degrees that every degree included various sanctions from sever to mild.

As previously described, assuming fulfillment of all conditions of duress or compulsion, no criminal responsibility and punishment is on coercion what man and woman, but as threat and forced others to commit a crime considered some kind of assistance in the crime that in paragraph A of Article 125 of the reform law of Islamic penal is mentioned as one of the examples of deputy in crime and in terms of Article 126 of the mentioned Act, if there is a certain penalty in law or religious law for the crime deputy, the same penalty will be implemented and for the punishment of those who commit adultery and its functions (sodomy, lesbianism, tafkhiz and leadership) only punishment has forecasted so it seems that now in other cases stipulated in the Article 126 and Article 68 of this Act, to coercion Tazir with Article 63 of mentioned law should be acted.

But in the answer to the second question: Who is responsible for the payment of dowry to duress? Adulterer or duress? The consensus of jurists is that because duress is stronger view than steward, the guarantee of dowry is on him, and if the issue wasn't social, we could say that woman can take its dowry from duress adulterer, but he after the payment can receive it from duress. (Najafi, the same, 55)

However, it seems that, the claim of duress is contrary to principle and therefore need to prove, but the phrase "if the certain is contrary to it" in Article 67 of the former Penal Code, this meant that the claim of duress is accepted in adultery without a reason, now in accordance with Article 218 reform Act IPC "in crimes of Hadd, when accused claims lack of knowledge or intension or existing one of the barriers of criminal responsibility at the time of the offense, if there is probability of truth of his speech, his claiming is accepted without need for evidence and swear" .

\section{Conclusion}

Talk about the criminal responsibility of Islam that is one of the human phenomenon of crime is one of the most important issues that is originated from the natural characteristics and the type of creation of human and why the jurists and lawyers in discussion about human responsibility, based on general conditions of obligation and analysis of the characteristics of the material and spiritual of human and explanation of freedom, authority, knowledge and other human abilities have analyzed different aspects and conditions of criminal responsibility.

One of the conditions of responsibility and assignments is authority, one can be obliged to preserve and respect for life, property, and dignity of the people that is free in his actions.

Although legislator, in accordance with the provisions of Article 54 and Articles 66, 111, 130, 166 and 189 of the Penal Code 1991, having authority in committing crimes of the issue of penalties as well as crimes of Haddi penalties, such as adultery, sodomy, lesbianism, intoxicant and robbery was considered the condition of proof of criminal responsibility and consequently punish, in Article 218 of the Penal Code in 2011 have also generally explained the necessity of the condition in all crimes so about punishment of those who make the others to commit crimes, have been silent.

Now according to the silence of law about the criminal responsibility of coercion in all alternatives of adultery crime and its functions is essential to act about each of the mentioned crimes by observing the legality of sanctions within the framework of the provisions of Article 167 of the Constitution and article 214 of the Criminal Procedure Code by referring to the legal texts and related fields of law and in accordance with generally accepted principles in criminal law discriminately, ie those that could determine the criminal responsibility of such persons on the basis of the provisions listed in the penal code, as punishment for duress adulterer according to the exact text of paragraph (D) of Article 225 and stipulated in paragraph 3 of article 126 of the law (deputy in crimes included Haddi whipping), their criminal responsibility based on the mentioned provisions can be determined, but in other cases, where the threat and force others to commit a crime is considered as some kind of assistance in crime, that in paragraph 1 of Article 125 of the Islamic penal law reform is mentioned as one of the examples of assistance in crime and based on Article 126 of the mentioned Act if there is a certain penalty for deputy in law or Islamic law, the same punishment will be implemented in law, and in law for punishing those who force others to commit a punishable crimes, only punishment is predicted, so seems that with implementing the mentioned law in other cases stipulated in this Law should be acted relying on the Article 
126 and Article 68 of this Act, to Tazir of coercion with Article 63 of the mentioned law acted one of the punishments alternative to imprisonment, an episode of care, free public services, fine, fine daily cash, deprivation of social rights, and until the before the implementing of the law must condemn to Tazir punishments in Article using the title of threat and coercion under Article 669 of the Penal Code adopted in 1991.

\section{References}

Amely- Sheikh Horr, Wasael Al- Shie, Volume XII, Fifth Edition, Almaktabah Al-Imamiya, Tehran 1401 BC. Ansary- Sheikh Morteza, Makasib, press information, Tabriz, 1978 BC.

Ardabili- Mohammad Ali, general criminal law, Volume II, ninth edition, Mizan publishing, Tehran, 2005.

Esfahany- Ayatollah Seyed Abolhasan, Vasilal Najat, Volume II, published by Dar al-Elm Ghom in 1979 BC.

Fazel Hendi, Kashfollesam, tenth velum, Darolkotob Eslamiya, Tehran, 1409 AH.

Feyz- Ali Reza, comparative and adaptation in criminal law of Islamic public, the first volume, first edition, published by Amir Kabir, Tehran, 1986.

Golduziyan- Iraj. Necessities of general criminal law, Eighth Edition, Mizan publication, Tehran, 2003.

Haly- Allama Abul Ghasem Najm al-Din, religions of Islam, Volume 2, Third Edition, published by the Institute of Esmailian, Ghom, 1409 AH.

Holy Quran.

Khoiy- Seyed Abolghasem, foundations of Takmela Al-Minhaj, Volume II, first printing, publication of Khorsandi, Tehran, 2011.

Mir Mohammad Sadeghi- Hossein, crimes against persons, first printing, Mizan publishing, Tehran, 2007.

Moein Mohammed, Persian dictionary of Moein, the first volume, sixth edition, Tehran Amir Kabir Publications, 1984.

Mohammady- Abol Hasan, Islamic criminal law, first edition, the center of Tehran University Press, 1995.

Najafy- Mohammad Hassan, Javaher al-Kalam (Hudud and Tazirat) The first volume, first printing, publication of Khorsandi, Tehran, 2011.

Ragheb Esfahani- Mohammed bin Hossein, words of the Quran, first and second volumes published by Mortazavi, Tehran 1990.

Saneay- Yosef, questions of justice, second edition, Mizan publishing, Tehran, 2005.

\section{Copyrights}

Copyright for this article is retained by the author(s), with first publication rights granted to the journal.

This is an open-access article distributed under the terms and conditions of the Creative Commons Attribution license (http://creativecommons.org/licenses/by/3.0/). 